\title{
Ecological Study of Bryophytes on Platanus orientalis L. Trees in Nainital (Western Himalaya)
}

\author{
Ravinder Bargali, Vishal Awasthi, Neerja Pande* \\ Department of Botany, D.S.B. Campus, Kumaun University, Nainital, India \\ Email: ${ }^{*}$ neerjapande2012@gmail.com
}

Received 1 November 2014; revised 1 December 2014; accepted 12 December 2014

Copyright (C) 2014 by authors and Scientific Research Publishing Inc.

This work is licensed under the Creative Commons Attribution International License (CC BY). http://creativecommons.org/licenses/by/4.0/

c) (i) Open Access

\begin{abstract}
The bryophytic vegetation associated with Platanus orientalis trees were studied and compared with other important tree species of Nainital. In total 27 mosses and liverworts belonging to 14 families with three morphological groups formed the principle component of Platanus orientalis tree bark. Based on IVI (Important Value Index), Regmatodon orthostegius together with Brachymenium capitulatum formed the pioneer community, while Herpetineuron toccoae formed the climax community on the Platanus orientalis stems. Comparison of the bryoflora of $P$. orientalis with other dominant trees of this locality indicated that 15 species were common, while 12 species viz., Didymodon vinealis (Brid.) R.H., Bryoerythrophyllum dentatum (Mitt.) Chen, Gemmabryum apiculatum (Schwägr.), Ditrichum heteromallum (Hedw.) Britt., Entodon chloropus Ren. \& Card., Cylindrothecium laetum (Griff.) Paris, Fabronia schensiana C. Muell., Lejeunea tuberculosa Stephani, Levierella neckeroides (Griff.), Regmatodon orthostegius Mont., Rhynchostegiella menadensis (Lac.) Bartr. and Stereophyllum fulvum (Harv.) Jaeg. were confined to the tree barks of $P$. orientalis.
\end{abstract}

\section{Keywords}

Epiphytic, Mosses, Platanus orientalis, Nainital

\section{Introduction}

Epiphytic bryophytes constitute an important and integral part of forest communities in and around Nainital. Species richness and host specificity of bryophytes in relation to a large number of phorophytes have been studied in western countries [1]-[5]. In India, epiphytic succession has been studied on tree trunks in a mixed

\footnotetext{
"Corresponding author.
}

How to cite this paper: Bargali, R., Awasthi, V. and Pande, N. (2014) Ecological Study of Bryophytes on Platanus orientalis L. Trees in Nainital (Western Himalaya). American Journal of Plant Sciences, 5, 3880-3888. 
oak-cedar forest in Kumaun Himalaya [6]. Tewari and Pant [7] studied bryophyte diversity on four oak species and three gymnosperms and listed a total of 90 moss and 22 liverwort taxa from the bark of these phorophytes in Nainital. Similarly, Pande et al. [8] reported 21 bryophyte taxa from the bark of Aesculus indica in Nainital. Joshi [9] reported 19 species of bryophytes from the phorophytes at higher altitude forests of Kumaun Himalaya i.e., Quercus semecarpifolia, Abies pindrow, Aesculus indica and Acer cappadocicum. Awasthi et al. [10] reported 17 bryophyte taxa from bark of Erythrina arborescens and 8 mosses from endemic plant Trachycarpus takil of Kumaun [11]. Bansal et al. [12] reported several bryophyte species on the bark of Thuja orientalis in Nagaland. Pande [13] studied the species richness and phytosociology of bryophytes in diverse habitats of Nainital. Pande and Joshi [14] [15] reported the species richness and phytosociology of bryophytes occurring on decaying logs at kharsu oak and silver fir forest. Nath et al. [16] studied the diversity of epiphytic moss flora of Pachmarhi Biosphere Reserve (Madhya Pradesh). Some other notable contributions on the ecological aspects of epiphytic bryophytes in Southern India and Western Ghats were made by Alam et al. [17] and Verma et al. [18].

The cool and humid climate of the Nainital supports a rich bryoflora on both evergreen and deciduous dominant tree species [8]. Platanus orientalis L. trees (Platanaceae) planted along the lake side of Nainital comprise both young and mature trees. Though not a native to the place, it supports a rich bryoflora on its stem. The species is subjected to the vehicular pollution caused by the heavy pressure of vehicles on the Mall road. This study was aimed to identify the mosses and liverworts on the bark of these trees and to find out the successional trends of the bryoflora, if any.

\section{Materials and Methods}

The phytosociological analysis of the epiphytic bryophytes was made for 40 trees of $P$. orientalis classified into 5 girth classes i.e., the cbh (A: $0-75 \mathrm{~cm}$; B: $76-150 \mathrm{~cm}$; C: $151-225 \mathrm{~cm}$; D: $226-300 \mathrm{~cm}$ and E: >300 cm) and each girth class consists of 8 trees. In each tree, 5 quadrats of $5 \times 5 \mathrm{~cm}$ size were placed randomly for the sampling of bryophytes along with the underlying bark. The plants were separated according to their growth form, habit and other distinguishing field characters and voucher specimens were stored in the Bryology Laboratory, Department of Botany, D.S.B. Campus, Kumaun University, Nainital. Slides of leaves and other parts were prepared in gum-chloral mounting media [19] and plants were identified following Gangulee [20]. Colour, texture and other characteristics of bark viz., $\mathrm{pH}$ and moisture content were also determined [21]. The vegetation data were calculated for frequency, density and abundance [22]. The Important Value Index of each species was determined as sum of relative frequency, relative density and relative abundance [23] [24]. The data were also computed for Sorenson's Similarity Index (SI) [25] among trees of the 5 girth classes by using the following formula.

$\mathrm{SI}=2 \mathrm{c} / \mathrm{a}+\mathrm{b}$; where $\mathrm{c}=$ number of species common to two girth classes, $\mathrm{a}=$ number of species at girth class 1 , and $b=$ number of species at girth class II.

Species composition of bryophytes on $P$. orientalis was compared with bibliographic data of bryophytes of other common and dominant phorophytes of Nainital [7] [8] [10].

\section{Results}

The physico-chemical characteristics of $P$. orientalis tree bark are given in Table 1 . In general, the bark is mildly acidic. The moisture content of the bark ranged between 105\% (girth class A) and 235\% (girth class D). The barks of trees belonging to girth class $\mathrm{E}$ had almost neutral $\mathrm{pH}$, high moisture content, rough surfaces with a large number of crack and crevices and supported maximum number of species (16 species). On the contrary, trees of lower CBH (girth class A) had acidic bark, low moisture content (105\%), smooth surfaces and supported only a limited number of species (9 species).

Among the bryophytes, principle component of Platanus bark was the mosses. In total 27 species of bryophytes belonging to 14 families were found (Table 2) including 2 leafy liverworts. The maximum number of species was represented by the family Bryaceae (5) followed by Entodontaceae (4) and Pottiaceae (4). Out of these 27 species, 8 species viz., Brachymenium capitulatum, Caduciella mariei, Ditrichum heteromallum, Frullania muscicola, Homaliothecium neckeroides, Lindbergia koelzii, Levierella neckeroides and Stereophyllum fulvum were strictly epiphytic in nature, while remaining species were also occurred as either epilithic (including rocks, retaining walls, stones) or as terrestrial.

Comparison of the bryoflora of $P$. orientalis with other dominant gymnosperm and angiosperm trees of this 
Table 1. Physico-chemical characteristics of $P$. orientalis tree bark.

\begin{tabular}{ccccccc}
\hline \multirow{2}{*}{ Parameters } & \multicolumn{5}{c}{ Bark characteristics according to girth class } \\
\cline { 2 - 6 } & A & B & C & D & E \\
Colour & Greyish green & Brownish black & Brownish black & Brownish black & Brownish black \\
Texture & Smooth & Rough & Rough & Rough & Rough \\
pH & 5.5 & 6.4 & 6.4 & 6.7 & 6.7 & 235 \\
\hline
\end{tabular}

Table 2. List of bryophyte species present on the Platanus orientalis tree.

\begin{tabular}{|c|c|c|c|c|}
\hline S. No. & Broyophyte species & $\begin{array}{l}\text { Morphological } \\
\text { form }\end{array}$ & $\begin{array}{l}\text { Growth } \\
\text { form }\end{array}$ & Family \\
\hline 1. & Didymodon vinealis (Brid.) R.H. Zander & Acrocarpous & Cushion & Pottiaceae \\
\hline 2. & Brachymenium capitulatum (Mitt.) Par. & Acrocarpous & Turf & Bryaceae \\
\hline 3. & Bryoerythrophyllum dentatum (Mitt.) P.C. Chen & Acrocarpous & Turf & Pottiaceae \\
\hline 4. & Bryum argenteum Hedw. & Acrocarpous & Turf & Bryaceae \\
\hline 5. & Bryum caespiticium L. ex Hedw. & Acrocarpous & Turf & Bryaceae \\
\hline 6. & Bryum capillare L. ex Hedw. & Acrocarpous & Turf & Bryaceae \\
\hline 7. & Gemmabryum apiculatum (Schwägr.) & Acrocarpous & Turf & Bryaceae \\
\hline 8. & Caduciella mariei (Besch.) Enroth & Pleurocarpous & Mat & Leptodontaceae \\
\hline 9. & Desmatodon gemmascens P.C. Chen & Acrocarpous & Turf & Pottiaceae \\
\hline 10. & Ditrichum heteromallum (Hedw.) E. Britton & Acrocarpous & Turf & Ditrichaceae \\
\hline 11. & Entodon chloropus Renauld \& Cardot & Pleurocarpous & Mat & Entodontaceae \\
\hline 12. & Cylindrothecium lateum (Griff.) Paris & Pleurocarpous & Mat & Entodontaceae \\
\hline 13. & Entodon rubicundus (Mitt.) A. Jaeger & Pleurocarpous & Mat & Entodontaceae \\
\hline 14. & Fabronia pusilla Raddi & Pleurocarpous & Mat & Fabroniaceae \\
\hline 15. & Fabronia schensiana Müll. Hal. & Pleurocarpous & Mat & Fabroniaceae \\
\hline 16. & Conomitrium subpalmatum (Müll. Hal.) A. Jaeger. & Acrocarpous & Turf & Fissidentaceae \\
\hline 17. & Frullania muscicola Steph. & Leafy liverwort & Mat & Frullaniaceae \\
\hline 18. & Herpetineuron toccoae (Sull. \& Lesq.) Card. & Pleurocarpous & Turf & Thuidiaceae \\
\hline 19. & Homalothecium neckeroides (Griff.) Paris & Pleurocarpous & Mat & Brachytheciaceae \\
\hline 20. & Hyophila involuta (Hook.) A. Jaeger & Acrocarpous & Turf & Pottiaceae \\
\hline 21. & Lejeunea tuberculosa Steph. & Leafy liverwort & Mat & Lejeuneaceae \\
\hline 22. & Lindbergia koelzii R.S. Williams & Pleurocarpous & Mat & Leskeaceae \\
\hline 23. & Levierella neckeroides (Griff.) O’Shea \& Matcham & Pleurocarpous & Mat & Entodontaceae \\
\hline 24. & Plagiothecium denticulatum (Hedw.) Shimp. & Pleurocarpous & Mat & Plagiotheciaceae \\
\hline 25. & Regmatodon orthostegius Mont. & Pleurocarpous & Mat & Leskeaceae \\
\hline 26. & Rhynchostegiella menadensis (Sande Lac.) E.B. Bartram & Pleurocarpous & Mat & Brachytheciaceae \\
\hline 27. & Stereophyllum fulvum (Harv.) A. Jaeger & Pleurocarpous & Mat & Stereophyllaceae \\
\hline
\end{tabular}

locality (Table 3) revealed that only 12 species i.e., Didymodon vinealis, Bryoerythrophyllum dentatum, Gemmabryum apiculatum, Ditrichum heteromallum, Entodon chloropus, Cylindrothecium laetum, Fabronia schensiana, Lejeunea tuberculosa, Levierella neckeroides, Regmatodon orthostegius, Rhynchostegiella menadensis and Stereophyllum fulvum were confined to the Plantanus bark and also formed the predominant component of epilithic and terrestrial habitat of this locality [7]. Remaining 15 species were common to other trees. Among the common species Herpetineuron toccoae has the broadest range of host trees followed by Desmatodon gemmascens, Fabronia pusilla, Plagiothecium denticulatum, Bryum capillare and Bryum argenteum.

Based on percent frequency, Regmatodon orthostegius was the most frequent species in lower girth classes (\% $\mathrm{F}=42.5$ and 32.5 in girth class $\mathrm{A}$ and $\mathrm{B}$, respectively), while Herpetineuron toccoae was the most frequent species in higher girth classes (\% F = 25 in $\mathrm{C}, 30$ in $\mathrm{D}$ and 37.5 in $\mathrm{E})$. 
Table 3. Comparison of epiphytic bryoflora of Platanus orientalis with other epiphytic flora of Nainital [7] [8] [10].

\begin{tabular}{|c|c|c|c|c|c|c|c|c|c|}
\hline \multirow{2}{*}{$\begin{array}{l}\text { Bryophyte species } \\
\text { on Platanus orientalis }\end{array}$} & \multicolumn{9}{|c|}{ Phorophytes } \\
\hline & EA & AI & PR & CD & CT & QLE & QF & QS & QL \\
\hline Didymodon vinealis & - & - & - & - & - & - & - & - & - \\
\hline Brachymenium capitulatum & - & - & - & + & - & + & + & + & - \\
\hline Bryoerythrophyllum dentatum & - & - & - & - & - & - & - & - & - \\
\hline Bryum argenteum & + & - & - & + & + & + & + & + & + \\
\hline Bryum caespiticium & + & - & - & - & - & - & - & - & - \\
\hline Bryum capillare & - & - & + & + & + & + & + & + & + \\
\hline Gemmabryum apiculatum & - & - & - & - & - & - & - & - & - \\
\hline Caduciella mariei & + & - & - & - & - & - & - & - & - \\
\hline Desmatodon gemmascens & + & - & + & + & + & + & + & + & + \\
\hline Ditrichum heteromallum & - & - & - & - & - & - & - & - & - \\
\hline Entodon chloropus & - & - & - & - & - & - & - & - & - \\
\hline Cylindrothecium laetum & - & - & - & - & - & - & - & - & - \\
\hline Entodon rubicundus & + & - & - & - & - & + & + & + & - \\
\hline Fabronia pusilla & + & - & + & + & + & + & + & + & + \\
\hline Fabronia schensiana & - & - & - & - & - & - & - & - & - \\
\hline Conomitrium subpalmatum & + & - & - & - & - & - & - & - & - \\
\hline Frullania muscicola & - & - & - & - & - & + & - & - & - \\
\hline Herpetineuron toccoae & + & + & + & + & + & + & + & + & + \\
\hline Homalothecium neckeroides & - & - & - & + & - & - & - & - & - \\
\hline Hyophila involuta & - & + & + & - & - & + & + & + & - \\
\hline Lejeunea tuberculosa & - & - & - & - & - & - & - & - & - \\
\hline Lindbergia koelzii & - & + & + & - & - & + & + & - & - \\
\hline Levierella neckeroides & - & - & - & - & - & - & - & - & - \\
\hline Plagiothecium denticulatum & - & + & + & + & + & + & + & + & + \\
\hline Regmatodon orthostegius & - & - & - & - & - & - & - & - & - \\
\hline Rhynchostegiella menadensis & - & - & - & - & - & - & - & - & - \\
\hline Stereophyllum fulvum & - & - & - & - & - & - & - & - & - \\
\hline
\end{tabular}

Abbreviations: $\mathrm{EA}=$ Erythrina arborescens; $\mathrm{AI}=$ Aesculus indica; $\mathrm{PR}=$ Pinus roxburghii; $\mathrm{CD}=$ Cedrus deodara $\mathrm{CT}=$ Cupressuss torulosa; $\mathrm{QLE}$ $=$ Quercus leucotrichophora; $\mathrm{QF}=$ Quercus floribunda; $\mathrm{QS}=$ Quercus semecarpifolia; $\mathrm{QL}=$ Quercus lanuginosa.

On the basis of density, $R$. orthostegius dominated in lower girth classes (3950 ind. $\mathrm{m}^{-2}$ and 3508 ind. $\mathrm{m}^{-2}$ in girth class A and B, respectively). While in higher girth classes, C. laetum (1688 ind. $\mathrm{m}^{-2}, 2960$ ind. $\mathrm{m}^{-2}$ and 2760 ind. $\mathrm{m}^{-2}$ in girth class $\mathrm{C}, \mathrm{D}$ and $\mathrm{E}$, respectively) was dominant (Table 4).

Data of IVI indicated that only two types of bryophytic communities were formed across the girth classes (Table 4). At trees of lower girth class (A and B), R. orthostegius together with B. capitulatum formed the community (IVI $=119.15$ and 73.02 in girth class A and B for $R$. orthostegius, while IVI $=64.86$ and 54.37 in girth class A and B for B. capitulatum). At higher girth classes (C and D), C. laetum formed the community (IVI $=45.88$ and 50.11 in girth class $\mathrm{C}$ and $\mathrm{D}$, respectively) with co-dominant species $H$. toccoae (IVI $=45.33$ and 45.67 in girth class $\mathrm{C}$ and $\mathrm{D}$, respectively). At the trees of maximum girth class $(\mathrm{E}), \mathrm{H}$. toccoae $(\mathrm{IVI}=44.96)$ forms the community with Caduciella mariei (IVI $=44.02)$.

The data on similarity index (Table 5) indicated that bryophytic vegetation of girth classes B and E had shown the maximum similarity ( $\mathrm{SI}=79 \%$ ) followed by B and D $(\mathrm{SI}=72 \%)$. The minimum resemblance was found between the vegetation at trees of girth classes A and C $(\mathrm{SI}=41 \%)$.

\section{Discussion}

Epiphytic bryophytes are often valuable environmental indicators [26]-[28]. The bryoflora on the barks of Platanus orientalis consisted of 27 taxa, out of which $7.4 \%$ were leafy liverworts and $92.6 \%$ were mosses. The 
Table 4. Vegetation data for the frequency (F), density (D), abundance (A) and Important Value Index (IVI) of the epiphytic bryophytes on different girth classes of Platanus orientalis trees.

\begin{tabular}{|c|c|c|c|c|c|c|}
\hline S. No. & Bryophyte species & F (\%) & D (ind. $\mathbf{m}^{-2}$ ) & A & $\mathbf{A} / \mathbf{F}$ & IVI \\
\hline \multicolumn{7}{|c|}{ Girth class A $(0-75 \mathrm{~cm})$} \\
\hline 1. & Brachymenium capitulatum & 20 & 1900 & 23.75 & 1.19 & 64.86 \\
\hline 2. & Bryum caespiticium & 7.5 & 508 & 17 & 2.27 & 26.7 \\
\hline 3. & Entodon chloropus & 2.5 & 70 & 7 & 2.8 & 8.39 \\
\hline 4. & Cylindrothecium laetum & 2.5 & 150 & 15 & 6 & 14.62 \\
\hline 5. & Frullania muscicola & 2.5 & 380 & 38 & 15.2 & 32.52 \\
\hline 6. & Herpetineuron toccoae & 2.5 & 60 & 6 & 2.4 & 7.61 \\
\hline 7. & Lejeunea tuberculosa & 2.5 & 90 & 9 & 3.6 & 9.95 \\
\hline 8. & Lindbergia koelzii & 2.5 & 170 & 17 & 6.8 & 16.18 \\
\hline 9. & Regmatodon orthostegius & 42.5 & 3950 & 23.23 & 0.55 & 119.15 \\
\hline \multicolumn{6}{|c|}{ Total } & 299.98 \\
\hline \multicolumn{7}{|c|}{ Girth class B (76 - $150 \mathrm{~cm})$} \\
\hline 1. & Brachymenium capitulatum & 22.5 & 2440 & 27.11 & 1.2 & 54.37 \\
\hline 2. & Bryoerythrophyllum dentatum & 2.5 & 60 & 6 & 2.4 & 5.35 \\
\hline 3. & Bryum caespiticium & 5 & 210 & 10.5 & 2.1 & 10.88 \\
\hline 4. & Bryum capillare & 2.5 & 320 & 32 & 12.8 & 19.3 \\
\hline 5. & Caduciella mariei & 12.5 & 1208 & 24.2 & 1.94 & 32.84 \\
\hline 6. & Cylindrothecium laetum & 10 & 1000 & 25 & 2.5 & 29.07 \\
\hline 7. & Fabronia pusilla & 2.5 & 88 & 9 & 3.6 & 6.94 \\
\hline 8. & Conomitrium subpalmatum & 5 & 528 & 26.5 & 5.3 & 20.97 \\
\hline 9. & Herpetineuron toccoae & 17.5 & 860 & 12.28 & 0.70 & 28.51 \\
\hline 10. & Lejeunea tuberculosa & 2.5 & 168 & 17 & 6.8 & 11.23 \\
\hline 11. & Regmatodon orthostegius & 32.5 & 3508 & 27 & 0.83 & 73.02 \\
\hline 12. & Rhynchostegiella menadensis & 2.5 & 100 & 10 & 4 & 7.49 \\
\hline \multicolumn{6}{|c|}{ Total } & 299.97 \\
\hline \multicolumn{7}{|c|}{ Girth class C (151 - $225 \mathrm{~cm})$} \\
\hline 1. & Didymodon vinealis & 2.5 & 80 & 8 & 3.2 & 6.71 \\
\hline 2. & Brachymenium capitulatum & 5 & 560 & 28 & 5.6 & 24.03 \\
\hline 3. & Bryum caespiticium & 5 & 200 & 10 & 2 & 10.95 \\
\hline 4. & Gemmabryum apiculatum & 7.5 & 328 & 11 & 1.47 & 14.82 \\
\hline 5. & Caduciella mariei & 15 & 708 & 11.83 & 0.79 & 25.29 \\
\hline 6. & Desmatodon gemmascens & 2.5 & 40 & 4 & 1.6 & 4.27 \\
\hline 7. & Ditrichum heteromallum & 2.5 & 40 & 4 & 1.6 & 4.27 \\
\hline 8. & Cylindrothecium laetum & 22.5 & 1688 & 18.78 & 0.83 & 45.88 \\
\hline 9. & Entodon rubicundus & 7.5 & 690 & 23 & 3.07 & 24.99 \\
\hline 10. & Fabronia pusilla & 5 & 480 & 24 & 4.8 & 21.12 \\
\hline 11. & Conomitrium subpalmatum & 7.5 & 250 & 8.33 & 1.11 & 12.6 \\
\hline 12. & Herpetineuron toccoae & 25 & 1600 & 16 & 0.64 & 45.33 \\
\hline 13. & Hyophila involuta & 2.5 & 20 & 2 & 0.8 & 3.07 \\
\hline 14. & Lejeunea tuberculosa & 10 & 750 & 19.25 & 1.92 & 25.71 \\
\hline 15. & Levierella neckeroides & 15 & 990 & 16.5 & 1.1 & 30.92 \\
\hline \multicolumn{6}{|c|}{ Total } & 299.96 \\
\hline \multicolumn{7}{|c|}{ Girth class D $(226-300 \mathrm{~cm})$} \\
\hline 1. & Brachymenium capitulatum & 2.5 & 360 & 36 & 14.4 & 17 \\
\hline 2. & Bryum argenteum & 7.5 & 1110 & 37 & 4.93 & 26.37 \\
\hline 3. & Bryum capillare & 2.5 & 310 & 31 & 12.4 & 14.87 \\
\hline
\end{tabular}




\begin{tabular}{|c|c|c|c|c|c|c|}
\hline \multicolumn{7}{|c|}{ Continued } \\
\hline 4. & Caduciella mariei & 22.5 & 1120 & 12.44 & 0.55 & 27.68 \\
\hline 5. & Cylindrothecium laetum & 27.5 & 2960 & 26.91 & 0.98 & 50.11 \\
\hline 6. & Entodon rubicundus & 5 & 230 & 11.5 & 2.3 & 9.07 \\
\hline 7. & Fabronia pusilla & 7.5 & 290 & 9.67 & 1.29 & 10.53 \\
\hline 8. & Fabronia schensiana & 2.5 & 180 & 18 & 7.2 & 9.33 \\
\hline 9. & Conomitrium subpalmatum & 15 & 640 & 10.67 & 0.71 & 18.48 \\
\hline 10. & Herpetineuron toccoae & 30 & 2460 & 20.5 & 0.68 & 45.67 \\
\hline 11. & Homalothecium neckeroides & 2.5 & 110 & 11 & 4.4 & 6.33 \\
\hline 12. & Lejeunea tuberculosa & 15 & 1590 & 26.5 & 1.77 & 31.29 \\
\hline 13. & Regmatodon orthostegius & 12.5 & 1710 & 34.2 & 2.74 & 33.25 \\
\hline \multicolumn{6}{|c|}{ Total } & 299.98 \\
\hline \multicolumn{7}{|c|}{ Girth class E (>300 cm) } \\
\hline 1. & Brachymenium capitulatum & 5 & 100 & 5 & 1 & 5.51 \\
\hline 2. & Bryum caespiticium & 2.5 & 350 & 35 & 14 & 14.03 \\
\hline 3. & Bryum capillare & 2.5 & 180 & 18 & 7.2 & 8.02 \\
\hline 4. & Gemmabryum apiculatum & 2.5 & 90 & 9 & 3.6 & 4.85 \\
\hline 5. & Caduciella mariei & 30 & 2270 & 18.92 & 0.63 & 44.02 \\
\hline 6. & Cylindrothecium laetum & 27.5 & 2760 & 25.09 & 0.91 & 48.1 \\
\hline 7. & Fabronia pusilla & 5 & 670 & 33.5 & 6.7 & 17.95 \\
\hline 8. & Conomitrium subpalmatum & 7.5 & 310 & 10.33 & 1.38 & 10.37 \\
\hline 9. & Herpetineuron toccoae & 37.5 & 1970 & 13.13 & 0.35 & 44.96 \\
\hline 10. & Hyophila involuta & 5 & 200 & 10 & 2 & 7.7 \\
\hline 11. & Lejeunea tuberculosa & 5 & 320 & 16 & 3.2 & 10.32 \\
\hline 12. & Levierella neckeroides & 2.5 & 280 & 28 & 11.2 & 11.55 \\
\hline 13. & Plagiothecium denticulatum & 2.5 & 160 & 16 & 6.4 & 7.32 \\
\hline 14. & Regmatodon orthostegius & 10 & 1350 & 33.75 & 3.37 & 27.01 \\
\hline 15. & Rhynchostegiella menadensis & 2.5 & 670 & 67 & 26.8 & 25.32 \\
\hline 16. & Stereophyllum fulvum & 2.5 & 320 & 32 & 12.8 & 12.97 \\
\hline \multicolumn{6}{|c|}{ Total } & 300 \\
\hline
\end{tabular}

Table 5. Similarity index among different girth classes.

\begin{tabular}{cccccc} 
& A & B & C & D & E \\
\hline A & 100 & 57 & 41 & 45 & 48 \\
B & & 100 & 57 & 72 & 79 \\
C & & & 100 & 57 & 71 \\
D & & & 100 & 55 \\
E & & & & & 100 \\
\hline
\end{tabular}

leafy liverworts belonged to 2 families (Frullaniaceae and Lejeuneaceae) while, the mosses were spread over to 12 families (Table 2). Among these mosses, 56\% are pleurocarpous and $44 \%$ are acrocarpous.

Interestingly, 7 species viz., Caduciella mariei, Ditrichum heteromallum, Frullania muscicola, Homalothecium neckeroides (Griff.) Par., Levierella neckeroides, Lindbergia koelzii and Stereophyllum fulvum were strictly epiphytic in nature as they were not reported from other habitat. The remaining species were either epilithic (including rocks, retaining walls, stones) or ground flora species [7].

The maximum number of species was represented by the family Bryaceae (5) followed by Entodontaceae (4) and Pottiaceae (4). Predominance of the acrocarpous mosses and more often of family Pottiaceae reveals the xeric nature of environment. The distribution pattern of the epiphytic bryophytes clearly exhibited that the number of species increased as the $\mathrm{pH}$ and moisture content increased along the successive girth classes (Table 4).

The study of epiphytes on trees of different ages within more or less same environment is a feasible method to 
study colonization and succession [29]. The barks of the young trees (cbh less than $75 \mathrm{~cm}$ ) had acidic nature (pH 5.5), low moisture content (105\%) with smooth texture created a substrate not congenial and thus providing a limited chance for establishment and growth of propagules of some of the pioneer species. The occurrence of Entodon chloropus, Frullania muscicola and Lindbergia koelzii in only trees of girth class A where the moisture content of the substrate is low, allude the xeric nature of these species and their abilities to sustain in adverse environmental condition as also evident from certain morphological adaptations like presence of water sac (in Frullania) and concave leaves. On the contrary, the barks of mature trees of Platanus (girth class E) had almost neutral $\mathrm{pH}$ (6.7), high moisture content (235\%) and rough in texture with a large number of cracks and crevices forming an ideal habitat for the establishment and growth of propagules of various species of bryophytes thus represent the climax association. At the tree barks of girth class E, 3 species namely, Plagiothecium, Stereophyllum and Rhynchostegiella invaded, exhibiting that these taxa are high moisture demanding. The old age trees having maximum cbh (girth class E) harbor maximum number of species. The number of species encountered in trees of different girth class was found in proportion to their respective moisture contents. Low moisture content of the barks of girth class D may be perhaps one of the reason that some of the species which invaded on barks of girth class $\mathrm{C}$ could not survive. The low moisture status of girth class $\mathrm{D}$ may be attributed to the dense canopy of the trees, inclination of the tree, so that the water flow could not trickle down to the base of the tree stems. The maximum value of similarity index in between trees of girth classes B and E denotes the transitional community association at the trees of girth class B and climax community at E. Coinciding, rough texture of the barks began from the trees of girth class B. It appears that moisture content and texture of the barks play key role in species distribution.

Among the species encountered, four species viz., Brachymenium capitulatum, Cylindrothecium laetum, Herpetineuron toccoae and Lejeunea tuberculosa exihibited broad ecological amplitude as these were present in all the girth classes. Comparison of the bryoflora of $P$. orientalis with other dominant phorophytes of this locality (Table 3) revealed that only 12 species were confined to the Plantanus bark and also formed the predominant component of epilithic and terrestrial habitat of this locality. Remaining 15 species were common to other trees. The barks of Quercus sp. were found the most similar with Platanus in terms of number of common species probably because of same physical characteristic and acidic $\mathrm{pH}$. On the other hand the barks of Aesculus indica and Erythrina arborescens represented the least similarity with Platanus in terms of number of common species among them probably because of difference in $\mathrm{pH}$ (acidic to neutral in Platanus and alkaline in former species).

$\mathrm{A} / \mathrm{F}$ ratio of all the bryophyte species in all girth classes of trees show more than 0.05 , thus reveal contagios distribution of all species [26]. Distribution of Caduciella mariei, Conomitrium subpalmatum and Fabronia pusilla in all girth classes except girth class A clearly indicates that they prefer the habitat having high moisture content and mild acidic to neutral $\mathrm{pH}$. On the basis of frequency, it can be stated that most of the species show rare (F = 10\% - 20\%) or accidental ( F < 10) occurrence. Regmatodon orthostegius in girth class A, Brachymenium capitulatum and Regmatodon orthostegius in girth class B, Cylindrothecium laetum in girth class $\mathrm{C}$, Caduciella mariei, C. laetum and Herpetineuron toccoae in girth class D and E showed moderate or intermediate distribution. On the basis of IVI value, it can be stated Regmatodon orthostegius together with Brachymenium capitulatum formed the pioneer community, while Herpetineuron toccoae formed the climax community of epiphytic bryoflora on Platanus orientalis. Some of the mosses like Didymodon vinealis, Bryoerythrophyllum dentatum, Desmatodon gemmascens, Ditrichum heteromallum, Fabronia pusilla, Homalothecium neckeroides, Plagiothecium denticulatum and Stereophyllum fulvum may have their accidental presence in this habitat as their propagules or spores might be aggregated in bark by means of wind dispersal or any other factor as they show very low frequency and very small number of individuals.

\section{Changes across the Girth Classes}

Changes in epiphytic vegetation on tree stems, where bark peels off periodically are not the same as found in succession occurring in land. The tree girth and bark roughness increase continuously with time. A few patterns across girth classes which become easily apparent in epiphytic communities of the present study are as follows:

1) Across the girth classes, the species number gradually increases with increase in girth class. The only exception is in girth class D where the species number decreases from 15 (girth class C) to 13 (girth class D). We also found marked changes in species richness in time. 
2) Distribution pattern of the moss species in relation to girth classes, in $P$. orientalis indicated that species like G. apiculatum, P. denticulatum, S. fulvatum, B. argenteum, F. schensiana and H. neckeroides showed their preferences to higher girth classes i.e. $\mathrm{C}, \mathrm{D}$ and $\mathrm{E}$ and they may be considered as late successional species. While E. chloropus, L. koelzii and F. muscicola are considered as early successional species (early colonizers) as they disappeared in higher girth classes.

3) In the present study F. muscicola appeared as early successional species, while at higher altitudes this species appeared as late successional species in Acer cappadocicum stems [9].

\section{Acknowledgements}

Two of the authors (Ravinder Bargali and Vishal Awasthi) are grateful to the University Grant Commission, New Delhi, India for providing the financial assistance under (UGC-BSR) Research Fellowship Scheme.

\section{References}

[1] McCune, B. and Antos, J.A. (1982) Epiphytic Communities of the Swan Valley, Montana. The Bryologist, 85, 1-2. http://dx.doi.org/10.2307/3243136

[2] Studlar, S.M. (1982) Host Specificity of Epiphytic Bryophytes near Mountane Lake, Virginia. The Bryologist, 85, 3750. http://dx.doi.org/10.2307/3243139

[3] Slack, N.G. and Glime, J.M. (1985) Niche Relationships of Mountain Stream Bryophytes. The Bryologist, 88, 7-18. http://dx.doi.org/10.2307/3242643

[4] Schmitt, C.K. and Slack, N.G. (1990) Host Specificity of Epiphytic Lichens and Bryophytes: A Comparison of the Adirondack Mountains (New York) and the Southern Blue Ridge Mountains (North Carolina). The Bryologist, 93, 257274. http://dx.doi.org/10.2307/3243509

[5] Wolf, J.H.D. (1993) Diversity Patterns and Biomass of Epiphytic Bryophytes and Lichens along an Altitudinal Gradient in the Northern Andes. Annals of the Missouri Botanical Garden, 80, 928-960. http://dx.doi.org/10.2307/2399938

[6] Tewari, M., Upreti, N., Pandey, P. and Singh, S.P. (1985) Epiphytic Succession on Tree Trunks in a Mixed Oak-Cedar Forest, Kumaun Himalaya. Vegetatio, 63, 105-112. http://dx.doi.org/10.1007/BF00044060

[7] Tewari, S.D. and Pant, G.B. (1994) Bryophytes of Kumaun Himalaya. Bishan Singh Mahendra Pal Singh. Shiva Offset Press, Dehradun.

[8] Pande, N., Rawat, S., Bargali, K. and Tewari, S.D. (2005) Diversity of Bryophytic Vegetation on Aesculus indica in Nainital. Proceedings of the National Academy of Science, India, 75(B), 135-140.

[9] Joshi, P. (1993) Biomass, Productivity and Nutrient Cycling in Epiphytic Bryophytes of Higher Altitude Forest Ecosystem. Ph.D. Thesis, Kumaun University, Nainital.

[10] Awasthi, V., Pande, R. and Pande, N. (2013) Bryophyte Diversity on Erythrina arborescens in Nainital. Proceedings of the National Academy of Sciences, India, 83(B), 461-464.

[11] Awasthi, V., Bargali, R. and Pande, N. (2013) Ecological Adaptations of Mosses on the Stems of Trachycarpus takil at Nainital. Oaks, 9, 60-63.

[12] Bansal, P., Nath, V. and Chaturvedi, S.K. (2011) Epiphytic Bryophytes on Thuja orientalis in Nagaland North-Eastern India. Bangladesh Journal of Plant Taxonomy, 18, 163-167. http://dx.doi.org/10.3329/bjpt.v18i2.9303

[13] Pande, N. (1984) Ecophysiological Studies of Bryophytes in Nainital Hills. Ph.D. Thesis, Kumaun University, Nainital.

[14] Pande, N. and Joshi, P. (2002) Seasonal Variation and Species Composition and Biomass of Bryophytes Growing on Decaying Logs in Kharsu Oak Forest of Central Himalaya. Journal of the Indian Botanical Society, 81, 21-25.

[15] Pande, N. and Joshi, P. (2004) Phytosociology. Biomass and Net Primary Production of Bryophyte Communities Growing on Decaying Logs in Silver Fir Forest at Higher Altitude of Central Himalaya. Geophytology, 32, 19-23.

[16] Nath, V., Pande, N., Asthana, A.K. and Gupta, R. (2012) Epiphytic Moss Flora of Pachmarhi Biosphere Reserve (M.P.): An Important Aspect of Bryophyte Diversity. National Academy Science Letters, 35, 195-200. http://dx.doi.org/10.1007/s40009-012-0015-0

[17] Alam, A., Verma, P.K., Asthana, G. and Yadav, S. (2011) Moss Flora of Palni Hills (India)—A Checklist. Archive for Bryology, 112, 1-8.

[18] Verma, P.K., Alam, A. and Srivastava, S.C. (2011) Status of Mosses in Nilgiri Hills (Western Ghat), India. Archive for Bryology, 102, 1-11.

[19] Watson, E.V. (1955) British Mosses and Liverworts. Cambridge University Press, Cambridge.

[20] Gangulee, H.C. (1969-1980) Mosses of Eastern India and Adjacent Regions. Vol. 1-III, Books and Allied Limited, 
Calcutta.

[21] Misra, R. (1968) Ecology Work Book. IBH, Calcutta, 244 p.

[22] Curtis, J.T. and McIntosh, R.P. (1950) The Interrelations of Certain Analytic and Synthetic Phytosociological Characters. Ecology, 31, 434-455. http://dx.doi.org/10.2307/1931497

[23] Curtis, J.T. (1959) The Vegetation of Wisconsin—An Ordination of Plant Community. University Wisconsin Press, Madison, $657 \mathrm{p}$.

[24] Cottom, G. and Curtis, J.T. (1956) The Use of Distance Measures in Phytosociological Sampling. Ecology, 35, 451460. http://dx.doi.org/10.2307/1930167

[25] Sorenson, T. (1948) A Method of Establishing Groups of Equal Amplitudes in Plant Sociology Based on Similarity of Species Content and Its Application to Analyses of the Vegetation on Danish Commons. Kongelige Danske Videnskabernes Selskab, Biologiske Skrifter, 5, 1-34.

[26] Barkman, J.J. (1958) Phytosociology and Ecology of Cryptogamic Epiphytes. Van Gorcum, Assen, 628 p.

[27] Bates, J.W., Roy, D.B. and Preston, C.D. (2004) Occurrence of Epiphytic Bryophytes in a "Tetrad" Transect across Southern Britain. 2. Analysis and Modelling of Epiphyte-Environment Relationships. Journal of Bryology, 26, 181-197. http://dx.doi.org/10.1179/037366804X5288

[28] Medina, R., Lara, F., Albertos, B., Draper, I., Garilleti, R. and Mazimpaka, V. (2010) Epiphytic Bryophytes in Harsh Environments: The Juniperus thuriferaforests. Journal of Bryology, 32, 23-31. http://dx.doi.org/10.1179/037366810X12578498135715

[29] Smith, A.J.E. (1982) Epiphytes and Epiliths. In: Smith, A.J.E., Ed., Bryophyte Ecology, Chapman and Hall, London, 191-227. http://dx.doi.org/10.1007/978-94-009-5891-3_7 
Scientific Research Publishing (SCIRP) is one of the largest Open Access journal publishers. It is currently publishing more than 200 open access, online, peer-reviewed journals covering a wide range of academic disciplines. SCIRP serves the worldwide academic communities and contributes to the progress and application of science with its publication.

Other selected journals from SCIRP are listed as below. Submit your manuscript to us via either submit@scirp.org or Online Submission Portal.
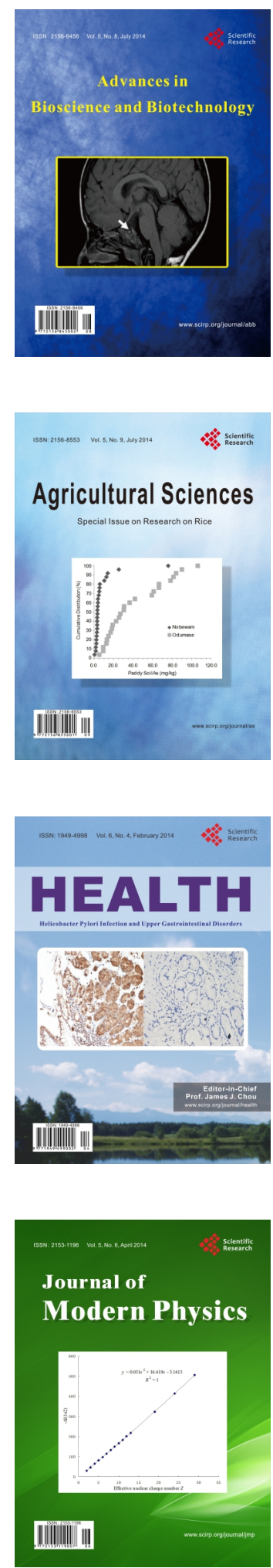
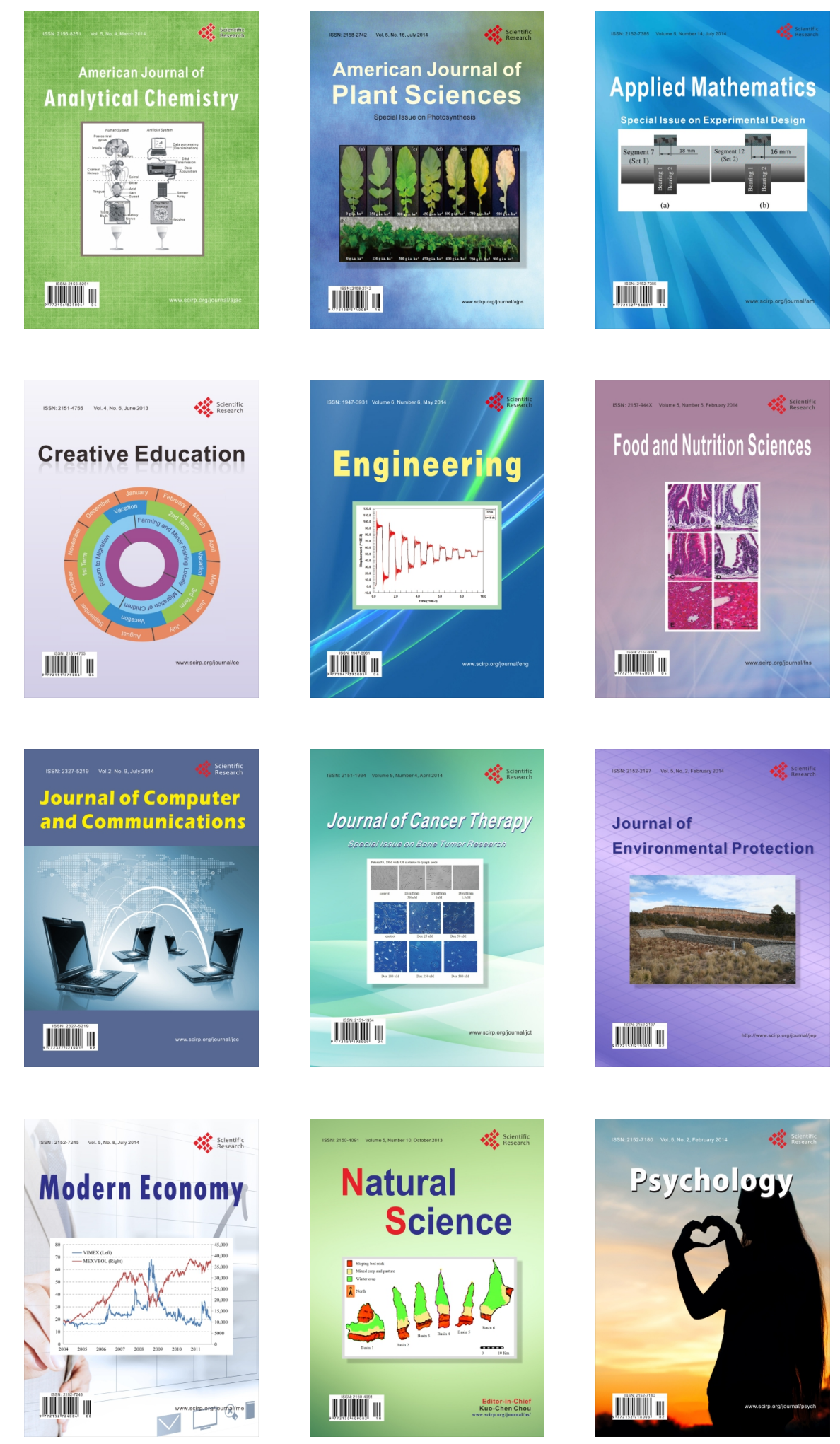